\title{
The Battle Over Bathrooms: Schools, Courts, and Transgender Rights
}

\author{
Rosemary R. Philips ${ }^{1}$
}

There is a battle afoot in the United States regarding the right of transgender students to use the bathrooms that match their gender identities. To say the law is unsettled in this area is an understatement. Almost half of the states have lawsuits against the federal government over this issue and there have been, and continue to be, numerous lawsuits between students and school districts. In addition to being unsettled, the law is constantly evolving as policies change and new legal challenges are filed and decided. This article provides an overview of the current state of the primary laws affecting transgender students, using the case of Gavin Grimm as a roadmap. Grimm is a transgender Virginia teen, whose lawsuit challenging his school district's bathroom policy was the first case to make its way to the United States Supreme Court. The primary legal challenges to school bathroom policies will be discussed, including the Equal Protection Clause of the $14^{\text {th }}$ Amendment and Title IX of the Education Act of 1972. [Article copies available for a fee from The Transformative Studies Institute. E-mail address: journal@transformativestudies.org Website: http://www.transformativestudies.org (C2017 by The Transformative Studies Institute. All rights reserved.]

KEYWORDS: Transgender, Gender, Sex, Bathrooms, Discrimination, Education.

Legal battles over restrooms are nothing new in the United States. In fact, legal struggles regarding bathroom use have a curiously long and storied history.

\footnotetext{
${ }^{1}$ Rosemary R. Philips is a Lecturer and Curriculum Coordinator in the Legal Studies Program at the State University of New York at Canton, as well as a practicing attorney. She graduated from Western Washington University with a Bachelor of Arts in Psychology and earned her Juris Doctor from the University of New Hampshire School of Law.
} 